\title{
Synthesis and Properties of meso-Arylporphyrin - closo-Decaborate Anion Conjugates
}

\author{
Kseniya A. Zhdanova, ${ }^{a}{ }^{@ 1}$ Andrey P. Zhdanov, ${ }^{\text {b }}$ Artem V. Ezhov, ${ }^{a}$ \\ Artem N. Fakhrutdinov, ${ }^{a}{ }^{\text {Natal'ya A. Bragina, }}{ }^{a}$ Konstantin Yu. Zhizhin, $^{\text {b@2 }}$ \\ Nikolay T. Kuznetsov, ${ }^{\mathrm{b}}$ and Andrey F. Mironov ${ }^{\mathrm{a}}$
}
${ }^{a}$ M.V. Lomonosov Moscow State University of Fine Chemical Technology, 119571 Moscow, Russian Federation
${ }^{\mathrm{b}}$ N.S. Kurnakov Institute of General and Inorganic Chemistry of Russian Academy of Sciences (IGIC RAS), 119991 Moscow, Russian Federation
${ }^{@ 1}$ Corresponding author E-mail: mishkina_ksyusha@mail.ru
${ }^{\circledR 2}$ Corresponding authorE-mail: zhizhin@igic.ras.ru

\begin{abstract}
New boron-porphyrin conjugates were synthesized based on 5,10,15,20-tetrakis(4-aminophenyl)porphyrin, 5-(4aminophenyl)-10,15,20-triphenylporphyrin, 5,10-bis(4-aminophenyl)-15,20-diphenylporphyrin and closo-decaborate anions $\left[B_{10} H_{10}\right]^{2-}$. Number of boron clusters varied from one to four. The structure of all compounds was confirmed using heteronuclear correlation methods $\left\{{ }^{1} \mathrm{H}^{13} \mathrm{C}\right\} \mathrm{HSQC}$ and $\left\{{ }^{1} \mathrm{H}^{13} \mathrm{C}\right\} \mathrm{HMBC}$. Spectral properties of the conjugates were evaluated based on electron absorption spectra and steady-state fluorescence. Such complexes are novel potential donor-acceptor systems.
\end{abstract}

Keywords: meso-Arylporphyrins, closo-decaborate anions, synthesis, luminescence, electron spectra, donor-acceptor systems.

\section{Синтез и свойства конъюгатов мезо-арияпорфиринов и анионов киозо-декабората}

\author{
К. А. Жданова, ${ }^{\mathrm{a}}{ }^{\circledR 1}$ А. П. Ж Жанов, ${ }^{\mathrm{b}}$ А. В. Ежов, ${ }^{\mathrm{a}}$ А. Н. Фахрутдинов, ${ }^{\mathrm{a}}$ \\ Н. А. Брагина, ${ }^{a}$ К. Ю. Жижин, ${ }^{\mathrm{b}}{ }^{\mathrm{a}}$ Н. Т. Кузнецов, ${ }^{\mathrm{b}}$ А. Ф. Миронов ${ }^{\mathrm{a}}$
}

${ }^{\mathrm{a}}$ Московский государственный университет тонких химических технологий имени М.В. Ломоносова, 119571 Москва, Россия

${ }^{\mathrm{b}}$ Институт общей и неорганической химии им. Н.С. Курнакова РАН, 119991 Москва, Россия

${ }^{\circledR 1}$ E-mail: mishkina_ksyusha@mail.ru

${ }^{\circledR 2}$ E-mail: zhizhin@igic.ras.ru

Были синтезированы новые бор-порфириновые конъюгаты на основе 5,10,15,20-тетракис(4-аминофенил)порфирина, 5-(4-аминофенил)-10,15,20-трифенилпорфирина, 5,10-бис(4-аминофенил)-15,20-дифенилпорфирина и клозо-декаборатного аниона $\left[B_{10} H_{10}\right]^{2-}$. Число присоединенньхх борных кластеров варьировалось от одного до четырех. Структура всех соединений была подтверждена с использованием методов гетероядерного коррелирования $\left\{{ }^{1} \mathrm{H}^{13} \mathrm{C}\right\} \mathrm{HSQC}$ и $\left\{{ }^{1} \mathrm{H}^{13} \mathrm{C}\right\}$ НMBC. Спектральные свойства конъюгатов были исследованы с помощьью методов электронной спектроскопии и флуоресиенции. Подобные комплексы являются потенциальными донорно-акцепторными системами.

Ключевые слова: мезо-Арилпорфирины, анион клозо-декабората, синтез, люминесценция, ЭСП, донорноакцепторные системы. 


\section{Introduction}

Development of modern technologies is inextricably linked to the alternative energy sources search, including a special role played by energy of sun. ${ }^{[1]}$ Photovoltaics based on inorganic semiconductors (multicrystalline silicon, binary compounds of arsenic, tellurium, selenium, etc.) have a long history and are successfully used in various industries. The main drawback of such systems is their high cost accompanied by many environmental problems. Photovoltaics based on organic dyes are easy to produce and have a relatively low cost, so creating DSSC by Grätzel gave a significant impetus to the search for new effective sensitizers. ${ }^{[2-4]}$ Significant advances have been made in creating sensitizers based on porphyrins and related compounds. ${ }^{[5]}$ This is due to their unique photophysical properties and resistance to photocatalytic degradation. ${ }^{[6,7]}$ The search of novel donoracceptor systems containing porphyrin for an effective solar energy conversion is in current interest of many works. ${ }^{[8,9]}$ The numerous synthetic approaches to the porphyrins functionalization determine their wide application for sensitizers design, and can be considered as a convenient platform upon receipt of the molecular and supramolecular systems of varying complexity.

One of the strategies to increase DSSC efficiency is to extend the absorption spectra of the sensitizer (in order to maximize the overlap with solar spectrum) and its shift to the red region, which can be achieved by increasing the coupling in the system ${ }^{[10,11]}$ or selection of appropriate donor group. ${ }^{[12-15]}$ Not less important characteristic of the DCCS is resistance to photochemical degradation. In this regard, the use of such "non-standard" donor functional groups such as closo-decaborate anion is very promising. Firstly, the anion $\left[\mathrm{B}_{10} \mathrm{H}_{10}\right]^{2-}$ bears a double negative charge and can exhibit properties of the donor and, secondly, its high stability and capability to reversible reduction-oxidation should significantly increase the resistance to photochemical degradation as the sensitizer.

Recently we have elaborated the approach to the boron-porphyrin conjugates with long-chain alkoxy-groups synthesis. ${ }^{[16]}$ In this work new donor-acceptor conjugates based on aminoporphyrins and boron cluster $\left[\mathrm{B}_{10} \mathrm{H}_{10}\right]^{2-}$ were received by reaction of nucleophilic addition. In this reaction porphyrin amino group reacts with nitrilium derivative of closo-decaborate anion $\left[2-\mathrm{B}_{10} \mathrm{H}_{9} \mathrm{~N} \equiv \mathrm{CMe}\right]$. The following amino porphyrins were synthesized and used: 5,10,15,20-tetrakis(4-aminophenyl)porphyrin, ${ }^{[17]}$ 5-(4aminophenyl)-10,15,20-triphenylporphyrin, ${ }^{[18]}$ 5,10-bis(4aminophenyl)-15,20-diphenylporphyrin. ${ }^{[18]}$ Then porphyrins were converted to metal complexes and reacted with boron clusters. The spectral properties of the obtained compounds were investigated by UV-vis spectrometry and steady-state fluorescence.

\section{Experimental}

All chemicals were obtained commercially and used as received unless otherwise noted. Pyrrole was purified by vacuum distillation; dichloromethane, hexane, acetonitrile, ethyl acetate were dried by standard methods prior to use. Column chromatography was performed on silica gel G 60 (Merck Inc, 40-70 mesh) TLC was performed on pre-coated silica gel glass plate (silica gel $60, \mathrm{~F}-254$, thickness $0.25 \mathrm{~mm}$ ) by Merck Inc. Benzaldehyde, $p$-nitrobenzaldehyde, potassium carbonate were purchased from Sigma-Aldrich and used without further purification. UV-vis spectra were recorded on TermoSpectronic Helios Alpha spectrophotometer in quartz cells of $0.5 \mathrm{~cm}$ thickness. All reported NMR results were obtained using Bruker 300 or $400 \mathrm{MHz}$ in $\mathrm{CD}_{3} \mathrm{CN}$. Mass-spectra were registered on «Ultraflex» (MALDI-TOF, matrix - DHB) equipment and ESI- MS Bruker MicroTOF-Q (Bruker Daltonics, Germany). Fluorescence spectra were recorded on Cary Eclipse (Agilent Technologies).

2-(Ethylydenammonio) nonahydro-closo-decaborate(1-) potassium $\mathrm{K}\left[2-\mathrm{B}_{10} \mathrm{H}_{9}\left(\mathrm{NCCH}_{3}\right)\right]$ was obtained as described in literature. ${ }^{[19]}$ To a suspension of $\mathrm{K}_{2}\left[\mathrm{~B}_{10} \mathrm{H}_{10}\right](0.02 \mathrm{~mol}, 4.00 \mathrm{~g})$ in $10 \mathrm{ml}$ of $\mathrm{CH}_{3} \mathrm{CN} 3 \mathrm{ml}$ of $\mathrm{CF}_{3} \mathrm{COOH}$ was added. The suspension was heated $\left(80^{\circ} \mathrm{C}\right)$ in dry argon atmosphere while stirring in $6 \mathrm{~h}$ until the gas detached. The solution was cooled to room temperature, then concentrated on a rotary evaporator. The resulting crystalline precipitate was filtered and washed with $\mathrm{CF}_{3} \mathrm{COOH}(3 \times 5 \mathrm{ml})$. The solid product was dried over $\mathrm{P}_{2} \mathrm{O}_{5}$. The yield of $\mathrm{K}\left[2-\mathrm{B}_{10} \mathrm{H}_{9} \mathrm{NCCH}_{3}\right]$ : 3.580 g (89.5\%). NMR ${ }^{11} \mathrm{~B}\left\{{ }^{2} \mathrm{H}\right\}-\left(\mathrm{CD}_{3} \mathrm{CN}\right) \delta \mathrm{ppm}: 1.3\left(\mathrm{~B}^{10}\right),-1.5$ $\left(\mathrm{B}^{1}\right),-20.1\left(\mathrm{~B}^{2}\right),-25.2\left(\mathrm{~B}^{3}, \mathrm{~B}^{5}, \mathrm{~B}^{6}, \mathrm{~B}^{9}\right),-27.8\left(\mathrm{~B}^{4}, \mathrm{~B}^{7}, \mathrm{~B}^{8}\right)$. NMR ${ }^{1} \mathrm{H}$ $\left(\mathrm{CD}_{3} \mathrm{CN}\right) \delta$ ppm: $2.59\left(3 \mathrm{H}, \mathrm{s},-\mathrm{CH}_{3}\right) . \mathrm{NMR}{ }^{13} \mathrm{C}\left(\mathrm{CD}_{3} \mathrm{CN}\right) \delta \mathrm{ppm}:$ $175.3(\mathrm{C} \equiv \mathrm{N}), 3.5\left(-\mathrm{CH}_{3}\right)$. IR (nujol, selected bands) $\mathrm{cm}^{-1}: 2545$, $2484, v(\mathrm{~B}-\mathrm{H}), 2359, v(\mathrm{C} \equiv \mathrm{N}), 1027, \delta(\mathrm{B}-\mathrm{B}-\mathrm{H})$.

[2-\{1-(5-(4-Phenylamino)-10,15,20-triphenylporphyrin $)\}$ ethylydenammoniononahydro-closo-decaborate)](1-) potassium (4). To the solution of porphyrin $1(0.16 \mathrm{mmol}, 0.100 \mathrm{~g})$ in $10 \mathrm{ml}$ of $\mathrm{CH}_{2} \mathrm{Cl}_{2} 0.80 \mathrm{mmol}$ of $\mathrm{K}\left[2-\mathrm{B}_{10} \mathrm{H}_{9}\left(\mathrm{NCCH}_{3}\right)\right](0.159 \mathrm{~g})$ in $\mathrm{CH}_{3} \mathrm{CN}$ $(10 \mathrm{ml})$ was added, and the mixture was refluxed and stirred for $8 \mathrm{~h}$ under nitrogen. The organic solution was evaporated in vacuo and chromatographed on silica gel G60 using gradient system $\mathrm{CH}_{2} \mathrm{Cl}_{2}: \mathrm{CH}_{3} \mathrm{CN} 3: 1$. Yield: $0.102(78.2 \%)$. UV-vis $\left(\mathrm{CH}_{3} \mathrm{CN}\right)$ $\lambda_{\max } \mathrm{nm}(\lg \varepsilon): 419$ (5.57); 515 (4.25); 554 (3.91); 589 (3.73); 646 (3.58). NMR ${ }^{11} \mathrm{~B}\left\{{ }^{1} \mathrm{H}\right\}-\left(\mathrm{CD}_{3} \mathrm{CN}\right) \delta \mathrm{ppm}: 1.4\left(\mathrm{~B}^{10}\right),-5.4\left(\mathrm{~B}^{1}\right),-15.7$ $\left(\mathrm{B}^{2}\right),-25.0\left(\mathrm{~B}^{3}, \mathrm{~B}^{5}, \mathrm{~B}^{6}, \mathrm{~B}^{9}\right),-28.3\left(\mathrm{~B}^{4}, \mathrm{~B}^{7}, \mathrm{~B}^{8}\right)$. NMR ${ }^{1} \mathrm{H}(400 \mathrm{MHz}$, $\left.\mathrm{CD}_{3} \mathrm{CN}\right) \delta$ ppm: $-2.76(2 \mathrm{H}, \mathrm{s}$, pyrrole $\mathrm{NH}), 2.35\left(3 \mathrm{H}, \mathrm{s}, \mathrm{CH}_{3}\right), 6.35$ $(1 \mathrm{H}, \mathrm{s}$, amidine $\mathrm{NH}), 7.60\left(2 \mathrm{H}, \mathrm{d}, J=8.18 \mathrm{~Hz}, \mathrm{H} 2_{\mathrm{An}}, \mathrm{H} 6_{\mathrm{An}}\right), 7.75$ $\left(6 \mathrm{H}, \mathrm{m}, \mathrm{H} 3_{\mathrm{ph}}, \mathrm{H} 5_{\mathrm{ph}}\right), 7.76\left(3 \mathrm{H}, \mathrm{m}, \mathrm{H} 4_{\mathrm{ph}}\right), 8.21\left(6 \mathrm{H}, \mathrm{d}, 7.45 \mathrm{~Hz}, \mathrm{H} 2_{\mathrm{ph}}\right.$, $\left.\mathrm{H} 6_{\mathrm{Ph}}\right), 8.26\left(2 \mathrm{H}, \mathrm{d}, J=8.18 \mathrm{~Hz}, \mathrm{H} 3_{\mathrm{An}}, \mathrm{H} 5_{\mathrm{An}}\right), 8.81(2 \mathrm{H}, \mathrm{d}, J=5.09 \mathrm{~Hz}$, $\mathrm{H} 3, \mathrm{H} 7), 8.86$ (4H, s, H12, H13, H17, H18), $8.90(2 \mathrm{H}, \mathrm{d}, J=5.09 \mathrm{~Hz}$, $\mathrm{H} 2, \mathrm{H} 8), 10.63(1 \mathrm{H}, \mathrm{s}$, aniline $\mathrm{NH}) . \mathrm{NMR}^{13} \mathrm{C}\left(100 \mathrm{MHz}, \mathrm{CD}_{3} \mathrm{CN}\right)$ $\delta$ ppm: $20.8\left(\mathrm{CH}_{3}\right), 118.4(\mathrm{C} 5), 120.5(\mathrm{C} 10, \mathrm{C} 20), 120.6$ (C15), $123.6\left(\mathrm{C} 2_{\mathrm{An}}, \mathrm{C} 6_{\mathrm{An}}\right), 126.9\left(\mathrm{C} 3_{\mathrm{ph}}, \mathrm{C} 5_{\mathrm{ph}}\right), 127.9\left(\mathrm{C} 4_{\mathrm{ph}}\right), 131.3(\mathrm{C} 2, \mathrm{C} 3$, $\mathrm{C} 7, \mathrm{C} 8, \mathrm{C} 12, \mathrm{C} 13, \mathrm{C} 17, \mathrm{C} 18), 134.7\left(\mathrm{C} 2_{\mathrm{ph}}, \mathrm{C} 6{ }_{\mathrm{ph}}\right), 135.6$ (aniline C2, C6), 136.2 (aniline C1), 141.6 (aniline C4), $142.1\left(\mathrm{C} 1_{\mathrm{ph}}\right), 164.1$ $(>\mathrm{C}=$ ). MS (ESI): $m / z 788.4573$ ( $A$ refers to the molecular weight

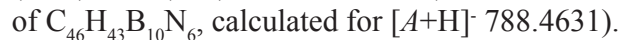

[2-\{1-(5,10-bis(4-Phenylamino)-15,20-diphenylporphyrin\} ethylydenammoniononahydro-closo-decaborate)](2-) potassium (5). To the solution of porphyrin $2(0.15 \mathrm{mmol}, 0.100 \mathrm{~g})$ in $10 \mathrm{ml}$ of $\mathrm{CH}_{2} \mathrm{Cl}_{2} 1.56 \mathrm{mmol}$ of $(\mathrm{K})\left[2-\mathrm{B}_{10} \mathrm{H}_{9}\left(\mathrm{NCCH}_{3}\right)\right](0.312 \mathrm{~g})$ in $\mathrm{CH}_{3} \mathrm{CN}$ $(10 \mathrm{ml})$ was added, and the mixture was refluxed and stirred for $12 \mathrm{~h}$ under nitrogen. The organic solution was evaporated in vacuo and chromatographed on silica gel $\mathrm{G} 60$ using $\mathrm{CH}_{2} \mathrm{Cl}_{2}: \mathrm{CH}_{3} \mathrm{CN}$ gradient from 5:1. Yield: $0.118(73 \%)$. UV-vis $\left(\mathrm{CH}_{3} \mathrm{CN}\right) \lambda_{\text {max }} \mathrm{nm}$ (lg e): 418 (5.54); 513 (4.23); 552 (3.88); 588 (3.71); 643 (3.55). NMR ${ }^{11} \mathrm{~B}\left\{{ }^{1} \mathrm{H}\right\}-\left(\mathrm{CDCl}_{3}\right) \delta$ ppm: $1.4\left(\mathrm{~B}^{10}\right),-5.4\left(\mathrm{~B}^{1}\right),-15.7\left(\mathrm{~B}^{2}\right),-25.0$

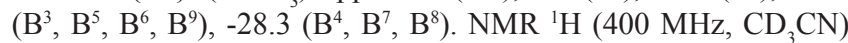
$\delta$ ppm: $-2.66(2 \mathrm{H}, \mathrm{s}$, pyrrole $\mathrm{NH}), 2.31\left(6 \mathrm{H}, \mathrm{s}, \mathrm{CH}_{3}\right), 7.01(2 \mathrm{H}, \mathrm{s}$, amidine $\mathrm{NH}), 7.47\left(4 \mathrm{H}, \mathrm{d}, J=7.89 \mathrm{~Hz}, \mathrm{H} 3_{\mathrm{An}}, \mathrm{H} 5_{\mathrm{An}}\right), 7.66(4 \mathrm{H}, \mathrm{m}$, $\left.\mathrm{H} 3_{\mathrm{ph}}, \mathrm{H} 5_{\mathrm{ph}}\right), 7.79\left(2 \mathrm{H}, \mathrm{m}, \mathrm{H} 4_{\mathrm{ph}}\right), 7.97\left(4 \mathrm{H}, \mathrm{d}, J=7.52 \mathrm{~Hz}, \mathrm{H} 3_{\mathrm{An}}, \mathrm{H} 5_{\mathrm{An}}\right)$ 8.06 ( $\left.4 \mathrm{H}, \mathrm{d}, J=7.15 \mathrm{~Hz}, \mathrm{H} 3_{\mathrm{ph}}{ }_{\mathrm{ph}}, \mathrm{H} 5_{\mathrm{ph}}\right), 8.75(4 \mathrm{H}, \mathrm{m}, \mathrm{H} 12, \mathrm{H} 13, \mathrm{H} 17$, H18), 8.81-8.91 (4H, m, H2, H3, H8, H7), 10.47 (2H, s, aniline $\mathrm{NH}) . \mathrm{NMR}{ }^{13} \mathrm{C}\left(100 \mathrm{MHz}, \mathrm{CDCl}_{3}\right) \delta \mathrm{ppm}: 18.85\left(\mathrm{CH}_{3}\right), 117.25$ (C5), 120.29 (C10, C20), 122.83 (C15), 126.65 (aniline $\mathrm{C} 2, \mathrm{C} 6$ ), $126.9\left(\mathrm{C}_{\mathrm{ph}}, \mathrm{C} 5_{\mathrm{ph}}\right), 127.77\left(\mathrm{C}_{\mathrm{ph}}\right), 131.57(\mathrm{C} 2, \mathrm{C} 3, \mathrm{C} 7, \mathrm{C} 8, \mathrm{C} 12$, 
C13, C17, C18), 134.13 (C2 $\left.{ }_{\mathrm{ph}}, \mathrm{C} 6_{\mathrm{ph}}\right), 135.0\left(\mathrm{C} 2_{\mathrm{An}}, \mathrm{C} 6_{\mathrm{An}}\right), 136.27$ $\left(\mathrm{Cl}_{\mathrm{An}}\right), 140.06\left(\mathrm{C}_{\mathrm{An}}\right), 141.42\left(\mathrm{Cl}_{\mathrm{ph}}\right), 164.57(>\mathrm{C}=)$. MS (ESI): $m / z 480.8348$ ( $A$ refers to the molecular weight of $\mathrm{C}_{48} \mathrm{H}_{56} \mathrm{~B}_{20} \mathrm{~N}_{8}$, calculated for $\left.\left\{[A+\mathrm{H}]^{2-} / 2\right\} 480.8357\right)$.

$[2-\{1-(5,10,15,20-$ Tetrakis(4-phenylaminoporphyrin $))\}$ ethylydenammoniononahydro-closo-decaborate)](4-) potassium (6). To the solution of porphyrin $3(0.115 \mathrm{mmol}, 0.100 \mathrm{~g})$ in $10 \mathrm{ml}$ of $\mathrm{CH}_{2} \mathrm{Cl}_{2} 6.0 \mathrm{mmol}$ of $(\mathrm{K})\left[2-\mathrm{B}_{10} \mathrm{H}_{9}\left(\mathrm{NCCH}_{3}\right)\right](1.20 \mathrm{~g})$ in $\mathrm{CH}_{3} \mathrm{CN}$ $(10 \mathrm{ml})$ was added, and the mixture was refluxed and stirred for $24 \mathrm{~h}$ under nitrogen. The organic solution was evaporated in vacuo and chromatographed on silica gel $\mathrm{G} 60$ using $\mathrm{CH}_{2} \mathrm{Cl}_{2}: \mathrm{CH}_{3} \mathrm{CN}$ gradient from 5:1. Yield: $0.154(70.3 \%)$. UV-vis $\left(\mathrm{CH}_{3} \mathrm{CN}\right) \lambda_{\operatorname{man}} \mathrm{nm}$ (lg ع): 420 (5.49); 517 (4.24); 553.8 (3.91); 591.6 (3.70); 647.6 (3.51). NMR ${ }^{11} \mathrm{~B}\left\{{ }^{1} \mathrm{H}\right\}-\left(\mathrm{CDCl}_{3}\right) \delta$ ppm: $1.4\left(\mathrm{~B}^{10}\right),-5.4\left(\mathrm{~B}^{1}\right),-15.7$ $\left(\mathrm{B}^{2}\right),-25.0\left(\mathrm{~B}^{3}, \mathrm{~B}^{5}, \mathrm{~B}^{6}, \mathrm{~B}^{9}\right),-28.3\left(\mathrm{~B}^{4}, \mathrm{~B}^{7}, \mathrm{~B}^{8}\right)$. NMR ${ }^{1} \mathrm{H}(400 \mathrm{MHz}$, $\left.\mathrm{CD}_{3} \mathrm{CN}\right) \delta$ ppm: $-2.76(2 \mathrm{H}, \mathrm{s}$, pyrrole $\mathrm{NH}), 2.37\left(12 \mathrm{H}, \mathrm{s}, \mathrm{CH}_{3}\right), 6.25$ $(4 \mathrm{H}, \mathrm{s}$, amidine $\mathrm{NH}), 7.14\left(8 \mathrm{H}, \mathrm{d}, J=8.07 \mathrm{~Hz}, \mathrm{H} 3_{\mathrm{ph}}, \mathrm{H} 5_{\mathrm{ph}}\right), 7.99$ $\left(8 \mathrm{H}, \mathrm{d}, J=8.25 \mathrm{~Hz}, \mathrm{H} 2_{\mathrm{ph}}, \mathrm{H} 6_{\mathrm{ph}}\right), 9.0$ (8H, m, H2, H3, H7, H8, H12, $\mathrm{H} 13, \mathrm{H} 17, \mathrm{H} 18), 10.66(4 \mathrm{H}, \mathrm{s}$, aniline $\mathrm{NH}) . \mathrm{NMR}{ }^{13} \mathrm{C}(100 \mathrm{MHz}$, $\left.\mathrm{CDCl}_{3}\right) \delta$ ppm: 23.8, 119.4, 121.5, 121.0, 123.8, 127.3, 127.5, 131.7, 134.3, 135.1, 135.8, 140.9, 142.4, 163.2. MS (ESI): $m / z 327.2667$ ( $A$ refers to the molecular weight of $\mathrm{C}_{52} \mathrm{H}_{82} \mathrm{~B}_{40} \mathrm{~N}_{12}$, calculated for $\left.\left\{[A+2 \mathrm{H}]^{4 /} / 4\right\} 327.2739\right)$.

General procedure for the synthesis of conjugate 4 metal complexes. A metal acetate (5 equiv.) in methanol was added to a conjugate ( 1 equiv.) in acetonitrile and the reaction was stirred and refluxed at $50{ }^{\circ} \mathrm{C}$ for $2 \mathrm{~h}$. The reaction mixture was concentrated and separated by column chromatography using dichloromethane:acetonitrile $(1: 1)$ system.

[2-\{1-(5-(4-Phenylamino)-10,15,20-triphenylporphyrin)\} ethylydenammoniononahydro-closo-decaborate)](1-) potassium zinc complex (4a) was obtained from conjugate 4 (20 mg, $0.024 \mathrm{mmol})$ and zinc acetate $(22 \mathrm{mg}, 0.12 \mathrm{mmol})$. Yield: $19 \mathrm{mg}$ (93.5 \%). UV-vis $\left(\mathrm{CH}_{3} \mathrm{CN}\right) \lambda_{\max } \mathrm{nm}(\mathrm{lg} \varepsilon): 423$ (5.31); 559 (3.98); 598 (3.53). MS (ESI): $\mathrm{m} / \mathrm{z} 850.3728$ ( $A$ refers to the molecular weight of $\mathrm{C}_{46} \mathrm{H}_{41} \mathrm{~B}_{10} \mathrm{~N}_{6} \mathrm{Zn}$, calculated for $[A+\mathrm{H}]^{-} 850.3766$ ).

[2-\{1-(5-(4-Phenylamino)-10,15,20-triphenylporphyrin)\} ethylydenammoniononahydro-closo-decaborate)](1-) potassium cobalt complex (4b) was obtained from conjugate 4 (20 mg, $0.024 \mathrm{mmol})$ and cobalt acetate $(21.4 \mathrm{mg}, 0.12 \mathrm{mmol})$. Yield: $20.2 \mathrm{mg}(95 \%)$. UV-vis $\left(\mathrm{CH}_{3} \mathrm{CN}\right) \lambda_{\max } \mathrm{nm}(\mathrm{lg} \varepsilon): 413$ (5.13); 557 (4.03), MS (ESI): $m / z 844.3822$ ( $A$ refers to the molecular weight of $\mathrm{C}_{46} \mathrm{H}_{41} \mathrm{~B}_{10} \mathrm{CoN}_{6}$, calculated for $[A]^{-844.3728)}$.

[2-\{1-(5-(4-Phenylamino)-10,15,20-triphenylporphyrin)\} ethylydenammoniononahydro-closo-decaborate)](1-) potassium copper complex (4c) was obtained from conjugate $4(20 \mathrm{mg}$, $0.024 \mathrm{mmol})$ and copper acetate $(22 \mathrm{mg}, 0.12 \mathrm{mmol})$. Yield: $19.2 \mathrm{mg}(90.3 \%)$. UV-vis $\left(\mathrm{CH}_{3} \mathrm{CN}\right) \lambda_{\text {max }} \mathrm{nm}(\lg \varepsilon): 412$ (5.11); 553 (3.78). MS (ESI): $m / z 849.3722$ ( $A$ refers to the molecular weight of $\mathrm{C}_{46} \mathrm{H}_{41} \mathrm{~B}_{10} \mathrm{CuN}_{6}$, calculated for $\left.[A]^{-} 849.3770\right)$.

[2-\{1-(5,10-Bis(4-phenylamino)-15,20-diphenylporphyrin\} ethylydenammoniononahydro-closo-decaborate)](2-) potassium zinc complex (5a) was obtained from conjugate 5 (30 mg, $0.029 \mathrm{mmol}$ ) and zinc acetate $(26.6 \mathrm{mg}, 0.14 \mathrm{mmol})$. Yield: $30.6 \mathrm{mg}$ (95.6\%). UV-vis $\left(\mathrm{CH}_{3} \mathrm{CN}\right) \lambda_{\max } \mathrm{nm}(\mathrm{lg} \varepsilon): 423$ (5.36); 550 (4.09); 590 (3.86). MS (ESI): $m / z 1061.5389$ ( $A$ refers to the molecular weight of $\mathrm{C}_{48} \mathrm{H}_{54} \mathrm{~B}_{20} \mathrm{~N}_{8} \mathrm{Zn}$, calculated for $\left.[A+\mathrm{K}]^{-} 1061.5406\right)$.

[2-\{1-(5,10-Bis(4-phenylamino)-15,20-diphenylporphyrin\} ethylydenammoniononahydro-closo-decaborate)](2-) potassium cobalt complex (5b) was obtained from conjugate 5 (30 mg, $0.029 \mathrm{mmol})$ and cobalt acetate $(25.6 \mathrm{mg}, 0.14 \mathrm{mmol})$. Yield: $29.7 \mathrm{mg}(94.3 \%)$. UV-vis $\left(\mathrm{CH}_{3} \mathrm{CN}\right) \lambda_{\max } \mathrm{nm}(\lg \varepsilon): 412$ (5.28); 555 (4.03). MS (ESI): $m / z 508.7933$ ( $A$ refers to the molecular weight of $\mathrm{C}_{48} \mathrm{H}_{54} \mathrm{~B}_{20} \mathrm{CoN}_{8}$, calculated for $\left\{[A]^{2-/ 2}\right\}$ 508.7905).

[2-\{1-(5,10-Bis(4-phenylamino)-15,20-diphenylporphyrin\} ethylydenammoniononahydro-closo-decaborate)](2-) potassium copper complex $(\mathbf{5 c})$ obtained from conjugate $5(30 \mathrm{mg}, 0.029 \mathrm{mmol})$ and copper acetate $(26.4 \mathrm{mg}, 0.14 \mathrm{mmol})$. Yield: $29.2 \mathrm{mg}(91.7 \%)$.
UV-vis $\left(\mathrm{CH}_{3} \mathrm{CN}\right) \lambda_{\max } \mathrm{nm}(\mathrm{lg} \varepsilon): 413$ (5.30); 554 (4.06). MS (ESI): $m / z 1060.5447$ ( $A$ refers to the molecular weight of $\mathrm{C}_{48} \mathrm{H}_{54} \mathrm{~B}_{20} \mathrm{CuN}_{8}$, calculated for $\left.[A+\mathrm{K}]^{-1} 1060.5411\right)$.

\section{Results and Discussion}

The aim of the work was to synthesize the conjugates of meso-aryl substituted porphyrins and closo-decaborate anion $\left[2-\mathrm{B}_{10} \mathrm{H}_{9} \mathrm{~N} \equiv \mathrm{CMe}\right]$. Thus the number of boron-containing functional groups was varied from one to four. The nitrilium derivatives of closo-decaborate anion $\left[2-\mathrm{B}_{10} \mathrm{H}_{9} \mathrm{~N} \equiv \mathrm{CMe}\right]$ have high reactivity in reaction of nucleophilic addition and $[2+3]$ cycloaddition reactions, that allows to use these anions as convenient synthons for the modification of natural compounds and complex structures, including substituted porphyrins. A series of boron-porphyrin conjugates were synthesized based on the reaction of nucleophilic addition of the amino substituted porphyrins to $\left[2-\mathrm{B}_{10} \mathrm{H}_{9} \mathrm{~N} \equiv \mathrm{CMe}\right]$ anion nitrilium derivative (Scheme 1). The process takes place under the following conditions: $70{ }^{\circ} \mathrm{C}$, a mixture of $\mathrm{CH}_{3} \mathrm{CN}_{\mathrm{C}} \mathrm{CH}_{2} \mathrm{Cl}_{2}$ $1: 1$; the yield of boron is close to quantitative (according to NMR ${ }^{11} \mathrm{~B}$ spectrum). Full conversion of the original nitrilium derivative was observed during 8-13 $\mathrm{h}$ depending on the number of connected boron fragments. Also we have obtained zinc, cobalt and copper metal complexes of compounds $\mathbf{4}, \mathbf{5}$. The metal complexes of the conjugates were prepared in two ways: by nucleophilic addition of aminoporphyrins metal complexes to the anion [ $\left.2-\mathrm{B}_{10} \mathrm{H}_{9} \mathrm{~N} \equiv \mathrm{CMe}\right]$, or by introducing the metal ion to the resulting conjugate (thus, the latter acts as a macrocyclic ligand).

Control of nucleophilic addition reaction and conversion degree was carried out using NMR ${ }^{11} \mathrm{~B}$ spectroscopy. Changes in ${ }^{11} \mathrm{~B}$ NMR spectra of the products are similar to that in NMR spectra in the case of primary aliphatic, aromatic amines ${ }^{[20]}$ and alkoxyporphyrin ${ }^{[16]}$ addition to nitrilium derivatives of closo-decaborate anion. Thus, the signal of the substituted boron atom is in $-14.7 \div-14.8 \mathrm{ppm}$ area, signal of apical peaks appears at $3.1 \div 3.0 \mathrm{ppm}\left(\mathrm{B}^{10}\right)$ and $-4.0 \div-4.1 \mathrm{ppm}\left(\mathrm{B}^{1}\right)$. The target conjugates were purified by column chromatography using silica gel and $\mathrm{CH}_{3} \mathrm{CN}: \mathrm{CH}_{2} \mathrm{Cl}_{2}$ mixture (1:1) as an eluent. All the compounds were obtained in high yields. The structures of 4, 5, 6 were confirmed by TLC, UV-vis and ${ }^{1} \mathrm{H}$, ${ }^{13} \mathrm{C},{ }^{11} \mathrm{~B}$ NMR spectroscopy, mass-spectrometry.

To confirm the conjugates structure the ${ }^{1} \mathrm{H},{ }^{13} \mathrm{C}$ NMR spectra were recorded using heteronuclear correlation methods $\left\{{ }^{1} \mathrm{H}{ }^{13} \mathrm{C}\right\}$ HSQC and $\left\{{ }^{1} \mathrm{H}{ }^{13} \mathrm{C}\right\}$ HMBC. Here we present the correlations of all signals for compound 4 . The signals of decaborate hydrogen atoms of $\mathbf{4}$ appear in ${ }^{1} \mathrm{H}$ spectrum as broad line at $0 \div 4.0 \mathrm{ppm}$. Almost complete correlation of the proton spectrum is performed by analyzing of multiplicity and position signals. The main difficulty was to establish the signals of hydrogen atoms of aniline and amidine fragments, and also hydrogen atoms $\mathrm{H} 2$ (6) and $\mathrm{H} 3$ (5) of aniline ring. HSQC experiment allowed to establish the chemical shifts of ${ }^{13} \mathrm{C}$ atoms which are linked by chemical bond with corresponding hydrogen atoms. The cross peaks at 8.90/131.6 ppm, 8.86/131.2 ppm and 8.81/130.7 ppm correspond to the interaction of hydrogen pyrrole atoms with their own carbon atoms. The carbon atoms in $\beta$-pyrrole positions give a broad signal at $131.3 \mathrm{ppm}$ in $\mathrm{NMR}{ }^{13} \mathrm{C}$ spectrum. 


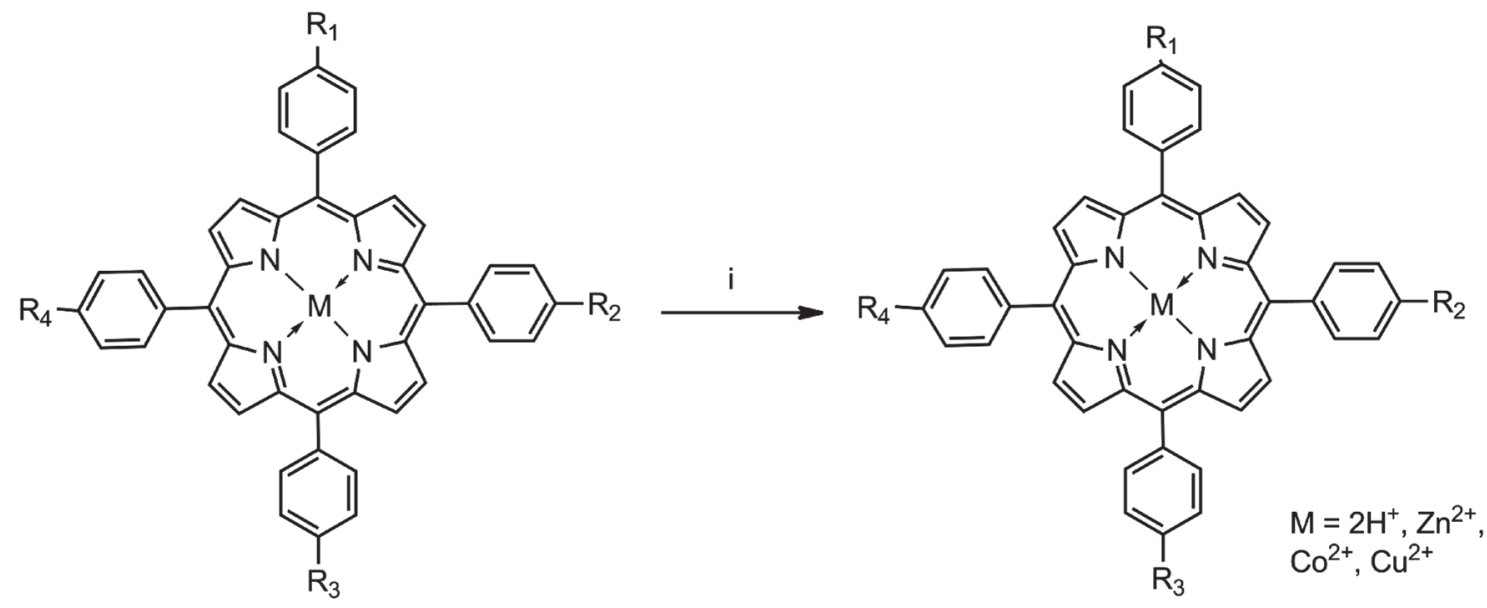

$\mathrm{R}_{1}=\mathrm{NH}_{2}, \mathrm{R}_{2}=\mathrm{R}_{3}=\mathrm{R}_{4}=\mathrm{H}(1) \quad \mathrm{R}_{1}=\mathrm{R}_{2}=\mathrm{NH}_{2}, \mathrm{R}_{3}=\mathrm{R}_{4}=\mathrm{H}(2) \quad \mathrm{R}_{1}=\mathrm{R}_{2}=\mathrm{R}_{3}=\mathrm{R}_{4}=\mathrm{NH}_{2}(3)$

$\mathrm{R}_{2}=\mathrm{R}_{3}=\mathrm{R}_{4}=\mathrm{H} ; \mathrm{R}_{1}=$

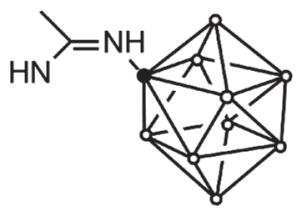

$\mathrm{R}_{1}=\mathrm{R}_{2}=\mathrm{R}_{3}=\mathrm{R}_{4}=$

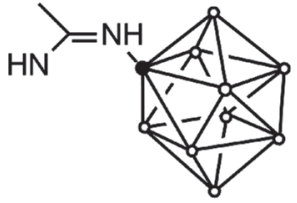

(6)

Scheme 1. $i$ : $\left[2-\mathrm{B}_{10} \mathrm{H}_{9} \mathrm{~N} \equiv \mathrm{CMe}\right]-70^{\circ} \mathrm{C}, \mathrm{CH}_{3} \mathrm{CN}: \mathrm{CH}_{2} \mathrm{Cl}_{2} 1: 1$.

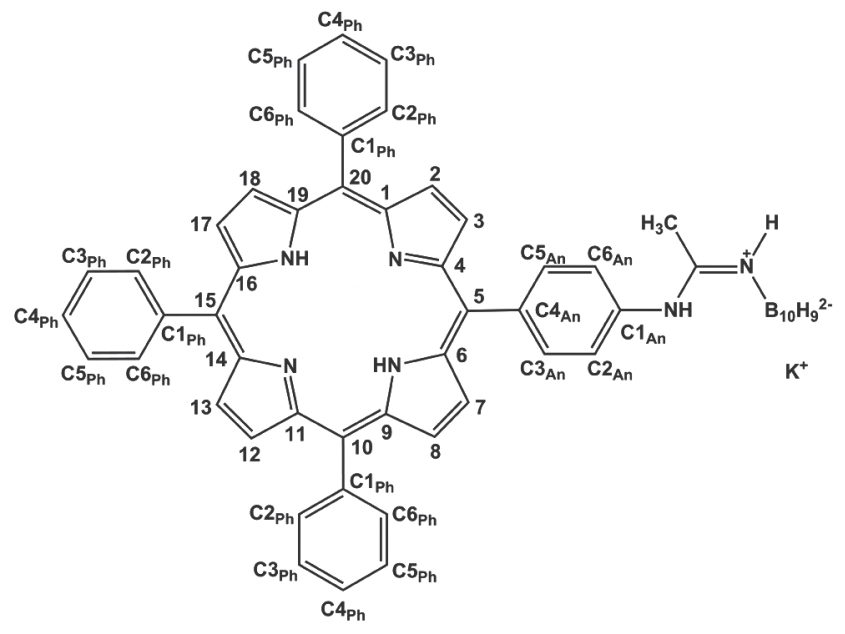

Figure 1. The structure and numeration of conjugate 4 .

Cross peaks at 10.63/123.6 ppm were observed in HMBC spectra. These peaks belong to NH hydrogen atom and carbon atom of aniline cycle. Consequently, $\mathrm{NH}$ is a part of aniline moiety, and $\mathrm{CH}$ hydrogen is referred to the second and sixth position of the ring. Further, the value of chemical shifts was identified by excluding the set of ${ }^{1} \mathrm{H}$ and ${ }^{13} \mathrm{C}$ atoms in the third and fifth positions. The corresponding cross- peak in HSQS is at 7.6/123.6 ppm (Figure 2). Also HMBC spectrum gives information about quarternary carbon atoms. Substituted carbon atoms of phenyl ring give cross peaks with hydrogen atoms in third and fifth positions at 7.76/142.1 ppm, $\mathrm{C} 1_{\mathrm{An}}$ atom was found at 8.26/136.2 ppm similarly. Carbon atoms of meso-positions interact through 3 chemical bonds with hydrogen atoms which are in $o$-position of the corresponding rings, as evidenced by the presence of crosspeaks at 8.26/118.4 ppm and 8.21/120.6 ppm. The rest signal that doesn't have cross-peaks in the HMBC is at $141.5 \mathrm{ppm}$ and belongs to $\mathrm{C} 4{ }_{\mathrm{An}}$. The signal of $\alpha$-carbon atoms of the pyrrole rings is shown in the spectrum as a broad line with the apex at $146.2 \mathrm{ppm}^{[21]}$ (Figure 3).

\section{Study of Spectral Properties}

The spectral properties of porphyrins 1, 2, their corresponding conjugates 4, 5 and metal complexes 4a-c, 5a-c were observed via electronic absorbance spectra and steady-state fluorescence. All spectra of the synthesized compounds are shown in Table 1 . UV-vis spectra of $\mathbf{4}$ and 5 of the same concentration $\left(C=5 \cdot 10^{-6} \mathrm{M}\right)$ don't differ, the Soret band of 4 is observed at $419 \mathrm{~nm}$, and of $\mathbf{5}-$ at $418 \mathrm{~nm}$. But luminescence spectrum of $\mathbf{5}$ is shifted by $7 \mathrm{~nm}$ in blue region comparing with that of $4\left(\lambda_{\text {ex }}=420 \mathrm{~nm}\right)$ (Figure 4). Luminescence intensity of $\mathbf{5}$ is increased compared with 


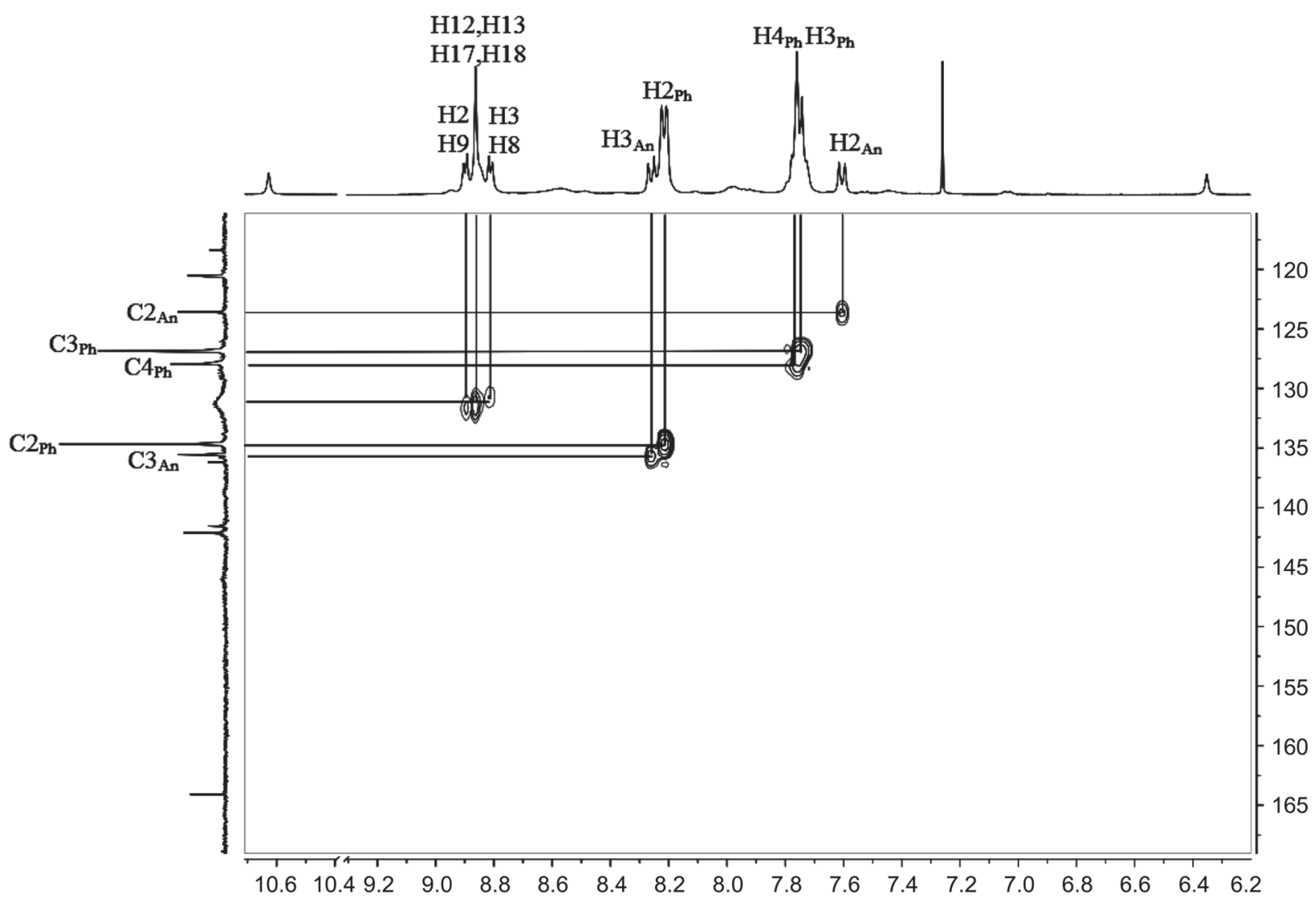

Figure 2. Fragment of the $\left\{{ }^{1} \mathrm{H}^{13} \mathrm{C}\right\}$ HSQC spectrum of 4 .

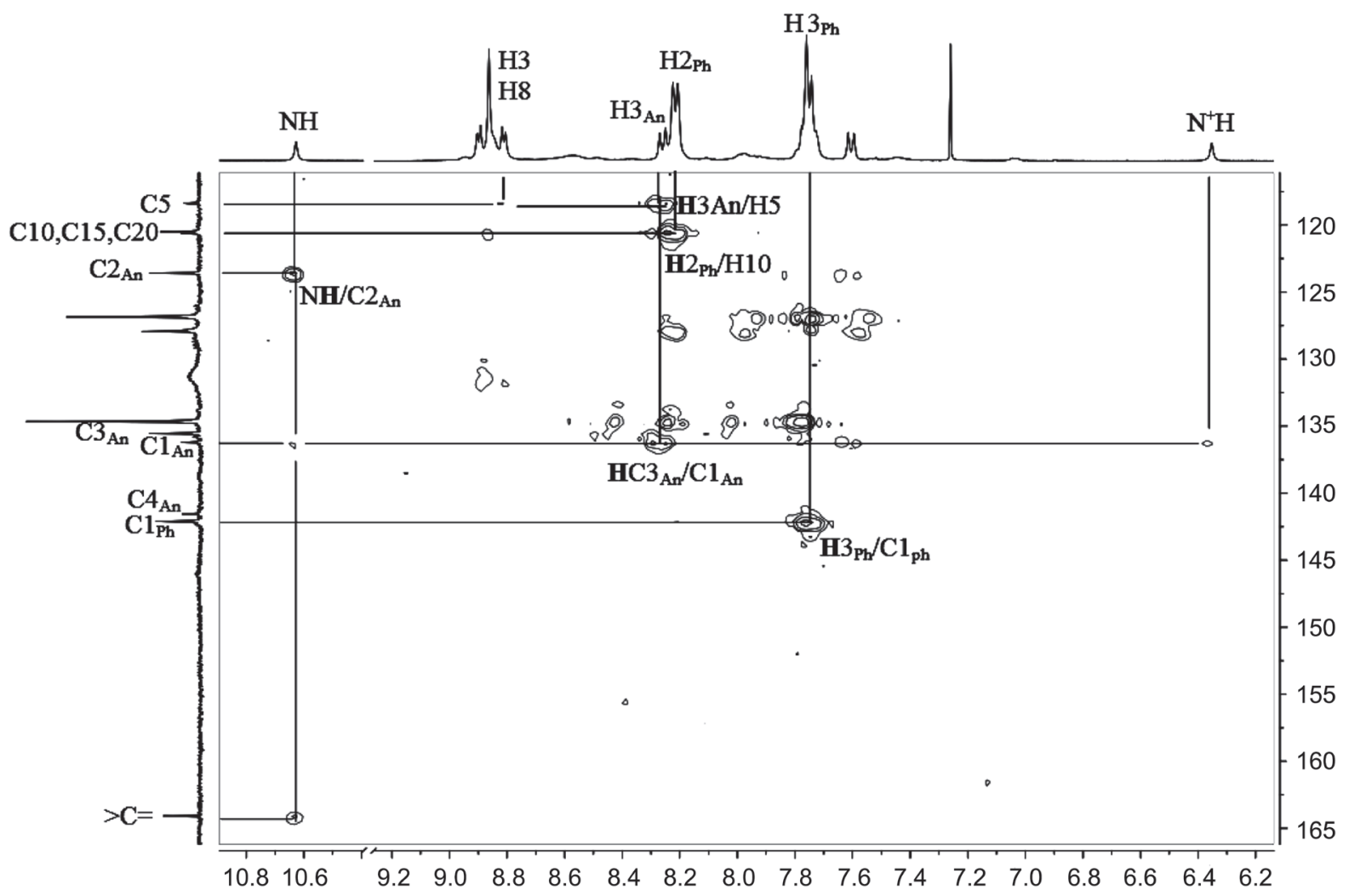

Figure 3. Fragment of the $\left\{{ }^{1} \mathrm{H}^{13} \mathrm{C}\right\} \mathrm{HMBC}$ spectrum of 4 . 
that of conjugate 4 . It can be explained by the introducing of additional boron anion in $\mathbf{5}$.

Table 1. UV-vis spectral data of the studied conjugates in $\mathrm{CH}_{3} \mathrm{CN}$.

\begin{tabular}{cc}
\hline $\begin{array}{c}\text { Com- } \\
\text { pound }\end{array}$ & $\lambda_{\max } / \mathrm{nm}(\lg \varepsilon)$ \\
\hline $\mathbf{4}$ & $419(5.57) ; 515(4.25) ; 554(3.91) ; 589(3.73) ; 646(3.58)$ \\
$\mathbf{5}$ & $418(5.54) ; 513(4.23) ; 552(3.88) ; 588(3.71) ; 643(3.55)$ \\
$\mathbf{6}$ & $420(5.49) ; 517(4.24) ; 553.8(3.91) ; 591.6(3.70) ; 647.6$ \\
$\mathbf{4 a}$ & $(3.51)$ \\
$\mathbf{4 b}$ & $423(5.31) ; 559(3.98) ; 598(3.53)$ \\
$\mathbf{4 c}$ & $413(5.13) ; 557(4.03)$ \\
$\mathbf{5 a}$ & $412(5.11) ; 553(3.78)$. \\
$\mathbf{5 b}$ & $423(5.36) ; 550(4.09) ; 590(3.86)$. \\
$\mathbf{5 c}$ & $412(5.28) ; 555(4.03)$. \\
\hline
\end{tabular}

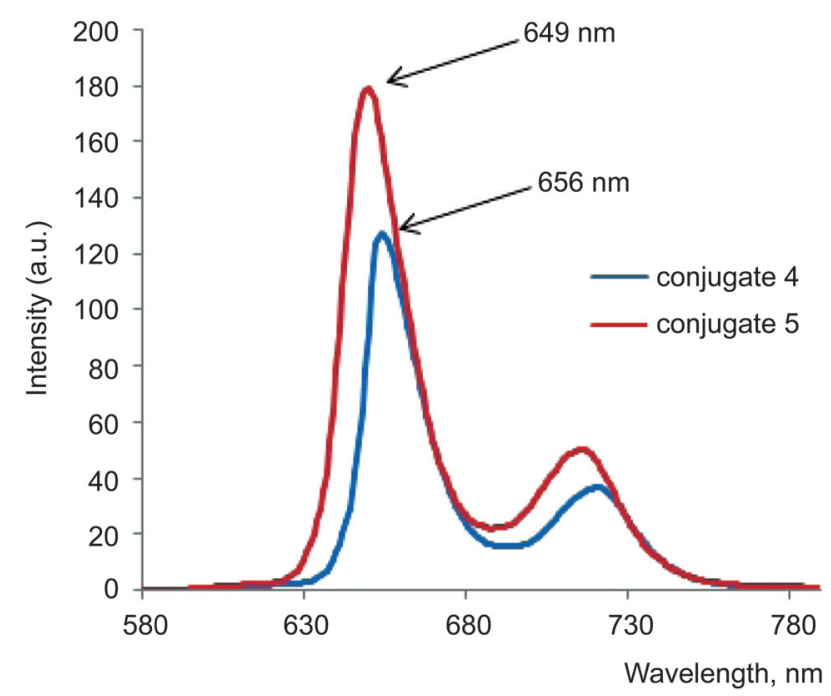

Figure 4. Fluorescence spectra of 4 and $5\left(\lambda_{e x}=420 \mathrm{~nm}\right)$.

UV-vis spectra of conjugate $\mathbf{4}$ and its zinc $\mathbf{4 a}$ and copper $4 \mathbf{c}$ complexes are shown in Figure 5. Comparing to the free base conjugate 4 and copper complex $4 \mathbf{c}$ some peculiarities were observed in the zinc $\mathbf{4 a}$ spectrum. There is a red shift of Soret band ( $8 \mathrm{~nm})$ in $\mathbf{4 a}$ compound (Figure 5). We assumed that in zinc complexes $\mathbf{4 a}$ it can be attributed to the dimer formation via self-complementary coordination. ${ }^{[22]}$ Probably, zinc cation can be coordinated by amidine group of closo-decaborate fragment. The same feature was observed for conjugate $\mathbf{5}$ and its zinc complex 5a (Figure 6), the red shift was $5 \mathrm{~nm}$. Such feature didn't reveal for copper and cobalt complexes. In the complexes $\mathbf{4 b}, \mathbf{c}$ and $\mathbf{5 b}, \mathbf{c}$ the Soret bands were blue shifted by 6-8 nm. In fluorescence spectra of $4 \mathbf{a}$ and $\mathbf{5 a}$ high luminescence was shown ( $84 \%$ and $87 \%$ relatively free bases $\mathbf{4}$ and $\mathbf{5}$, respectively) at the same concentration $\left(C=5 \cdot 10^{-6} \mathrm{M}\right)$, while luminescence of cobalt complexes was of $10 \%$ relatively free base conjugates, and in the copper complexes it almost didn't observe (less than $1 \%$ ) (Figure 7).

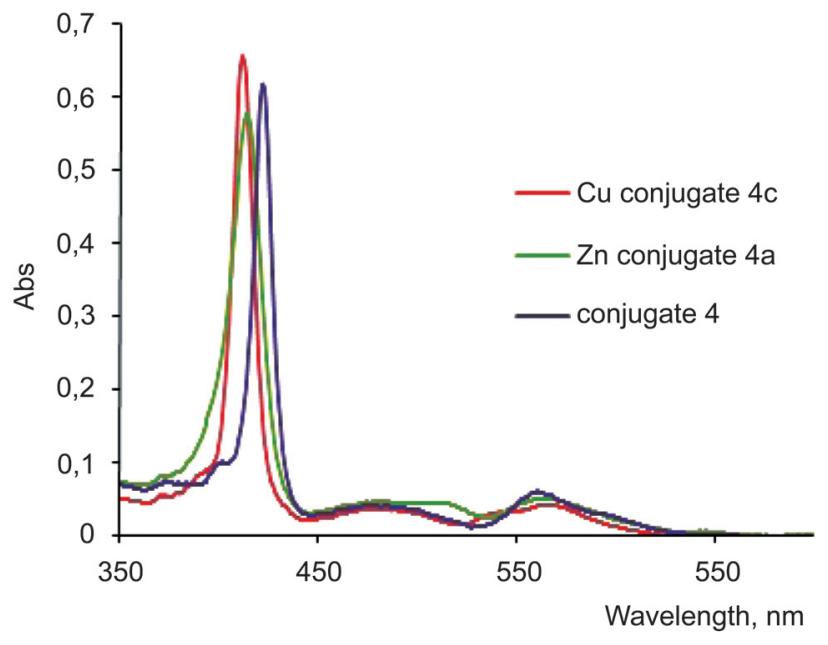

Figure 5. UV-vis spectra of $\mathbf{4}, \mathbf{4 a}, \mathbf{4} \mathbf{c}$ in $\mathrm{CH}_{3} \mathrm{CN}\left(C=5 \cdot 10^{-6} \mathrm{M}\right)$.

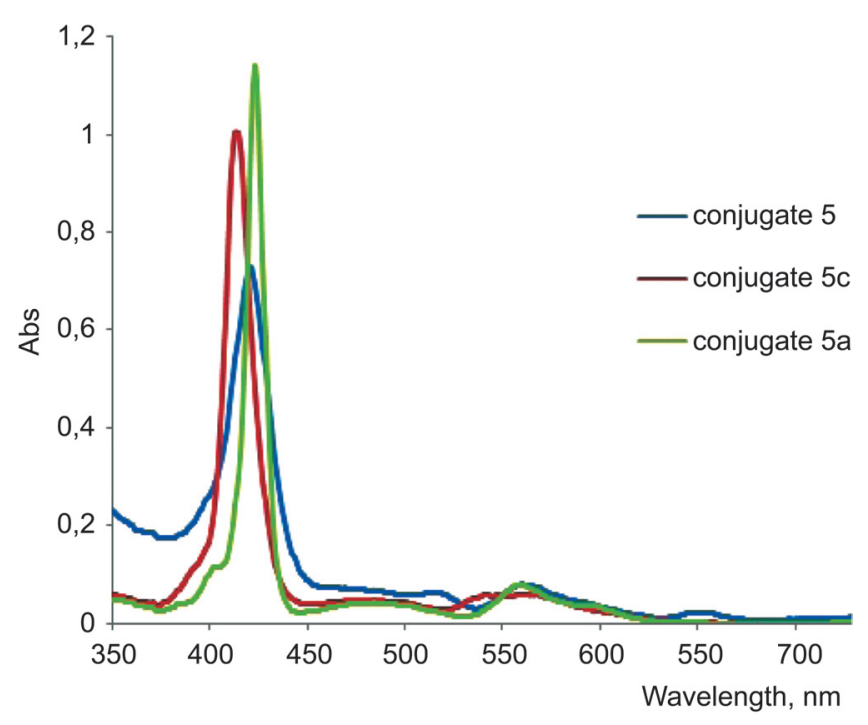

Figure 6. UV-vis spectra of 5, 5a, 5c in $\mathrm{CH}_{3} \mathrm{CN}\left(C=5 \cdot 10^{-6} \mathrm{M}\right)$.

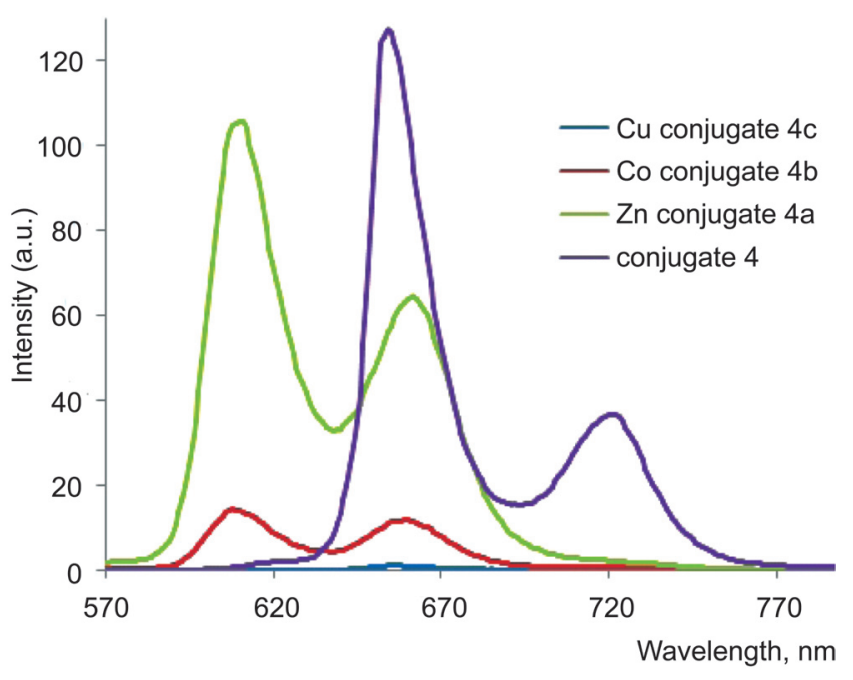

Figure 7. Fluorescence spectra of $\mathbf{4}, \mathbf{4 a}, \mathbf{4 b}, \mathbf{4} \mathbf{c}\left(\lambda_{\mathrm{ex}}=420 \mathrm{~nm}\right)$. 
meso-Arylporphyrin - closo-Decaborate Anion Conjugates

In future the spectral and electrochemical investigations will be continued.

\section{Conclusions}

In summary, we have synthesized new mesoarylporphyrin - closo-decaborate conjugates by nucleophilic addition reacton with high yields. We worked out the procedures for preparation and isolation of conjugates for chemical design of donor-acceptor supramolecular assemblies. The structures of the obtained compounds were confirmed by UV-vis and ${ }^{1} \mathrm{H},{ }^{13} \mathrm{C},{ }^{11} \mathrm{~B}$ NMR spectroscopy, ESI-MS mass-spectrometry. Revealed spectral properties need to be studied in future.

Acknowledgements. The authors thank Russian Foundation for Basic Research (grant № 13-03-00525a), 13-03-90459 (Ukr_f_a), 13-03-12046 (ofi_m).

\section{References}

1. Balzani V., Credi A., Venturi M. ChemSusChem 2008, 1, 26-58.

2. O'Regan B., Grätzel M. Nature 1991, 353, 737-740.

3. Hagfeldt A., Boschloo G., Sun L., Kloo L., Pettersson H. Chem. Rev. 2010, 110, 6595-6663.

4. Spitler M.T., Parkinson B.A. Acc. Chem. Res. 2009, 42, $2017-$ 2029.

5. Wang Q., Campbell W.M., Bonfantani E.E., Jolley K.W., Officer D.L., Walsh P.J., Gordon K., Humphry-Baker R., Nazeeruddin M.K., Grätzel M. J. Phys. Chem. B 2005, 109, 15397-15409.

6. Li L.-L., Diau E. W.-G. Chem. Soc. Rev. 2013, 42, 291-304.
7. Zamilatskov I.A., Savinkina E.V., Volov A.N., Grigoriev M.S., Lonin I.S., Obolenskaya L.N., Ponomarev G.V., Koifman O.I., Kuzovlev A.S., Kuzmicheva G.M., Tsivadze A.Yu. Macroheterocycles 2012, 5, 308-314.

8. Aratani N., Kim D., Osuko A. Acc. Chem. Res. 2009, 42, 19221934

9. Mironov A.F. Macroheterocycles 2011, 4, 186-208.

10. Hayashi S., Tanaka M., Hayashi H., Eu S., Umeyama T., Matano Y., Araki Y., Imahori H. J. Phys. Chem. C 2008, 112, 15576-15585.

11. Daphnomili D., Sharma G.D., Biswas S., Thomas K.R.J., Coutsolelos G. J. Photochem. Photobiol., A 2013, 253, 88-96.

12. Hsieh C.-P., Lu H.-P., Chiu C.-L., Lee C.-W., Chuang S.-H., Mai C.-L., Yen W.-N., Hsu S.-J., Diau E.W.-G., Yeh C.-Y. J. Mater. Chem. 2010, 20, 1127.

13. Ishida M., Hwang D., Koo Y.B., Sung J., Kim D.Y., Sessler J.L., Kim D. Chem. Commun. 2013, 49, 9164-9166.

14. Lee M.J., Seo K.D., Song H.M., Kang M.S., Eom Y.K., Kang H.S., Kim H.K. Tetrahedron Lett. 2011, 52, 3879-3882.

15. Seo K.D., Lee M.J., Song H.M., Kang H.S., Kim H.K. Dyes Pigm. 2012, 94, 143-149.

16. Zhdanova K.A., Zhdanov A.P., Ezhov A.V., Bragina N.A., Zhizhin K.Yu., Ushakova I.P., Mironov A.F., Kuznetsov N.T. Russ. Chem. Bull. 2014, 63, 194-200.

17. Semeikin A.S., Koifman O.I., Berezin B.D. Khim. Geterotsikl. Soedin. 1982, 10, 1354 (in Russ.).

18. Luguya R., Jaquinod L., Fronczek F.R., Vicente M.G.H., Smith K.M. Tetrahedron 2004, 60, 2757-2763.

19. Zhdanov A.P.,Polyakova I.N., Razgonyaeva G.A.,Zhizhin K.Y., Kuznetsov N.T. Russ. J. Inorg. Chem. 2011, 56, 847-855.

20. Dou D., Mavunkal I.J., Bauer J.A.K., Knobler C.B., Hawthorne M.F., Shore S.G. Inorg. Chem. 1994, 33, 6432-6434.

21. Ladomenou K., Lazarides T., Panda M.K., Charalambidis G., Daphonomili D., Coutsolelos A.G. Inorg. Chem. 2012, 51, 10548-10556.

22. Morisue M., Morita T., Kuroda Y. Org. Biomol. Chem. 2010, 8, 3457-3463. 